\title{
Detection of Cavities and Weak Zones underneath the Break Pressure Tanks at An-Nuwfaliyah, Libya
}

\author{
Fathi A. Swaid and Khaled Elmahishi
}

\begin{abstract}
Existence of cavities and weak zones on chalky limestone and gypsum was explored in an underneath break pressure tanks by using Ground Penetrating Radar (GPR) method even the geotechnical method was used. Therefore, three different frequencies range of ground penetrating radar were used in order to cover different depths under the tanks foundation. The GPR survey pinpointed the positions of many anomalies which exist underneath tank (I). The anomalies can be a cavity or a type of formation of high reflection of signal indicating unfastened type of formation which may turn to a cavity at any time. However, the geotechnical result which represented in drillings at selected locations confirmed the existence of these cavities nearby or extending underneath tank (I) at the depths of $1 \mathrm{~m}$ to $5.0 \mathrm{~m}$.
\end{abstract}

Index Terms-Ground penetrating radar, break pressure tanks, cavities, an-nuwfaliyah.

\section{INTRODUCTION}

Cavities and voids detection is one of primary objectives of geophysical investigations in the shallow subsurface profiles. Commonly applied geophysical techniques for this purpose include gravity method, electrical resistivity imaging, seismic refraction and ground penetrating radar (GPR), [1]-[5]. GPR has become in the last 20 years the most important method for investigations of shallow depth, because different conditions for its successful application are usually in shallow subsurface profiles. Some applications are related to shallow depth penetration which rarely exceeds 1-10 m using GPR systems with high frequency antennas, usually between $200 \mathrm{MHz}$ and $900 \mathrm{MHz}$ [6]-[8].

\section{SITE DESCRIPTION AND FIELD WORK}

At An-Nuwfaliyah region, Libya, The GPR techniques have been used to detecting cavities and weak zones underneath the break pressure tanks (tank I \& tank II) as shown in Fig. 1. Both tanks are placed on a relatively high ground and cover an area of approximately $8000 \mathrm{~m} 2$. The investigation area is covered by tertiary age of Al-Kums formation composed of marly and chalky limestone and gypsum. This is over lied by quaternary age of Holocene, composed mainly of recent wadi deposits, proflovial and flovio eolian deposits mostly consists of silt, fine sand and gravel, [9].

Therefore, the total capacity of the two tanks is $33,000 \mathrm{~m}^{3}$. Each tank consists of two-cell (A \& B) with rectangular

Manuscript received November 30, 2013; revised April 13, 2014.

Fathi A. Swaid is with Man-made River Water Utilization Authority, Middle Region, Libya (e-mail: fagswaid@yahoo.com.au). shape provided with its own inlet, outlet, overflow, washout and leakage inspection systems. The plan dimensions of the tank (from outside of walls) are $52.85 \times 56.8 \mathrm{~m}$ with clear inside height of $6.8 \mathrm{~m}$. The floor of each cell is composed of three $15 \times 15 \mathrm{~m}$ panels, $300-\mathrm{mm}$ thick. Each panel accommodates nine $400 \times 400 \mathrm{~mm}$ columns whose bases are thickened parts of the tank floor $2 \times 2 \mathrm{~m}$ and $400 \mathrm{~mm}$-thick [10].

Both tanks were created in 1996 to reducing the water pressure which coming through the pipes network of the Man-made river project, and in turn distribute the water to 177 farms of An-Nuwfaliyah agriculture project, [10]. Since 2008 , one of the break pressure tanks exhibited a problem of foundation damage due to the development of cavity underneath. The Great Man-made River Utilization Authority (GMMRUA) being the owner requested an investigation of the problem. As a result this study aims to investigate the nature and possible cause of cavity that developed underneath tanks foundation. Also aims to sizing up of cavities and their spread over. These are done by field observation and measurement adopting suitable engineering and geophysical techniques.

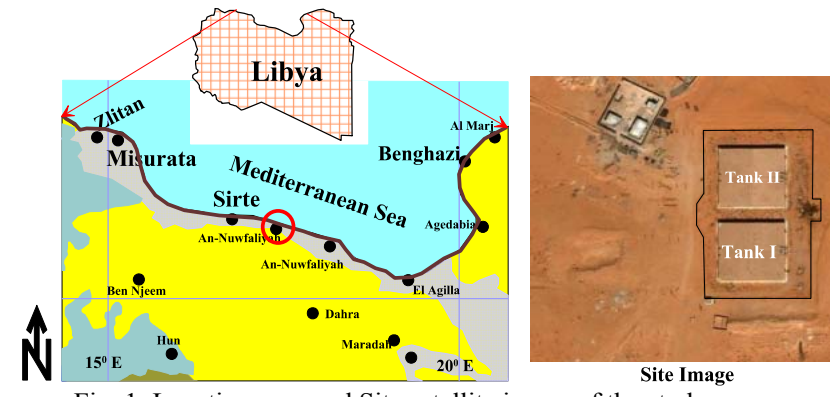

Fig. 1. Location map and Site satellite image of the study area.

\section{Methodology}

The purpose of geotechnical investigation is to obtain knowledge of the type of formation below tanks foundation. Based on site visits and visual inspection of the tanks foundation system no sign of bearing capacity failure or excessive settlement is likely to exist. The problem was apparently limited to the observed cavity. Furthermore the structural damage is also limited to cavity area. Therefore the geotechnical investigation program did not include any exploration work inside the tanks in order to avoid destruction of the structure system.

The program was only limited to drilling of boreholes around the tanks. The use of test pits was excluded to avoid causing any instability of the structure and connected services. The exposed profile near the overflow pipe was very helpful in understanding the typical formation of the 
area.

Five boreholes of $10 \mathrm{~m}$ depth were drilled at positions around the tanks. It aimed at exploring the subsurface condition and obtain knowledge of the ground formation that exists under the tanks. Fig. 2 shows the layout of the tanks and the position of drilled boreholes. There were some difficulties to drill boreholes closer to the tank because of the existence of chambers or having no access for the drilling rig. Therefore, rotary drilling machine type Acker soil-max was used for borehole drilling, Samples recovered during drilling for laboratory testing and rock cores were also taken. Both core recovery and quality designation were recorded. Field work was conducted according to BS 5930, [11].

GPR methods measure the travel time of an electromagnetic wave transmitted from a transmitter antenna, reflected from the subsurface, and received via receiver antenna. The principles of the GPR method have been described extensively in the literature (e.g. [1], [6]. It survey is a useful method for shallow engineering investigations, [12]-[15]. The most important advantage of ground penetrating radar survey technique is that no physical contact between the transmitter and receiver antenna and the subsoil is necessary. The GPR measurements have been conducted inside and outside the both tanks in order to delimitate eventual cavities. Inside tanks only one direction, noted as $\mathrm{X}$ axis have been conducted, (Fig. 3). Profiles have been mainly done with a $400 \mathrm{MHz}$ antenna, but verification tests have been done with $200 \mathrm{MHz}$ and $900 \mathrm{MHz}$ ).

TABLE I: SUMMARY OF THE SOIL PROPERTIES

\begin{tabular}{|c|c|c|c|c|c|c|c|c|c|c|}
\hline $\begin{array}{l}\text { S. } \\
\text { No. }\end{array}$ & $\begin{array}{l}\text { B.H } \\
\text { No. }\end{array}$ & $\begin{array}{l}\text { Sample D } \\
(\mathrm{m})\end{array}$ & $\begin{array}{l}\text { Gravel } \\
\text { C. } \%\end{array}$ & $\begin{array}{l}\text { Sand } \\
\text { C. } \%\end{array}$ & $\begin{array}{l}\text { Fines } \\
\text { C. } \%\end{array}$ & $\begin{array}{l}\text { Liquid } \\
\text { L\% }\end{array}$ & $\begin{array}{l}\text { Plastic } \\
\text { L\% }\end{array}$ & $\begin{array}{l}\text { Moisture } \\
\text { C. } \%\end{array}$ & $\begin{array}{l}\text { Specific } \\
\text { Gravity }\end{array}$ & $\begin{array}{l}\text { Soil Classf. } \\
\text { USCS }\end{array}$ \\
\hline 1 & 1 & $0.0-1.0$ & 44.47 & 35.9 & 19.63 & 25.1 & 19.7 & 14.94 & 2.76 & GC-GM \\
\hline 2 & 1 & $1.0-2.0$ & 8.02 & 58.93 & 33.06 & 67.47 & 35.25 & 15.16 & 2.63 & SC-SM \\
\hline 3 & 1 & $5.0-6.0$ & 24.5 & 32.36 & 43.15 & 73.51 & 487.22 & 18.1 & 2.67 & SM \\
\hline 4 & 2 & $0.0-1.0$ & 28.71 & 34.9 & 36.39 & 32.65 & 31.87 & 2.83 & 2.59 & SM \\
\hline 5 & 2 & $1.0-2.0$ & 34.19 & 43.79 & 22.02 & N.P & N.P & 11.33 & 2.67 & SM \\
\hline 6 & 2 & $3.0-4.0$ & 34.49 & 29.78 & 35.73 & 86.27 & 45.57 & 62.17 & 2.48 & GM \\
\hline 7 & 3 & $1.0-2.0$ & 54.83 & 31.81 & 13.37 & N.P & N.P & 15.7 & 2.69 & GM \\
\hline 8 & 3 & $2.0-3.0$ & 30.79 & 37.56 & 31.66 & N.P & N.P & 4.67 & 2.7 & S.M \\
\hline 9 & 3 & $4.0-5.0$ & 15.66 & 31.41 & 52.93 & 56.4 & 37.1 & 34.38 & 2.75 & $\mathrm{MH}$ \\
\hline 10 & 4 & $1.0-2.0$ & 7.53 & 34.41 & 58.06 & 29.59 & 16.65 & 9.31 & 2.65 & CL \\
\hline 11 & 5 & $0.0-1.0$ & 42.55 & 39.19 & 18.26 & N.P & N.P & 10.13 & 2.65 & GM \\
\hline 12 & 5 & $2.0-3.0$ & 7.07 & 60.51 & 32.42 & 47.4 & 17.48 & 17.48 & 2.69 & $\mathrm{SC}$ \\
\hline 13 & 5 & $4.0-5.0$ & 30.04 & 24.33 & 45.63 & 143.37 & 60.73 & 23.02 & 2.62 & MG \\
\hline
\end{tabular}

TABLE II: The RESUlt of THE ChEMICAL ANALysis of THE SoIL SAMPLES

\begin{tabular}{lcccccc}
\hline Sample & $\begin{array}{c}\text { Depth } \\
(\mathrm{m})\end{array}$ & $\begin{array}{c}\text { Silicon } \\
\text { Dioxide } \\
+ \\
\text { Insoluble } \\
\text { Matter \% }\end{array}$ & $\begin{array}{c}\text { Sulfur } \\
\text { Trioxide } \\
\mathrm{So}_{4} \%\end{array}$ & $\begin{array}{c}\text { Sulphates } \\
\mathrm{SO}_{4} \%\end{array}$ & $\begin{array}{c}\text { Calcium } \\
\text { Oxide } \\
\mathrm{CaO} \%\end{array}$ & $\begin{array}{c}\text { Aluminium } \\
\text { Oxide \% }\end{array}$ \\
\hline B.H. 1 & $4.5-5.0$ & 14.81 & 4.88 & 5.856 & 29.3 & 1.86 \\
B.H. 2 & $2.0-3.0$ & 6.39 & 1.26 & 1.512 & 30.44 & 1.98 \\
B.H. 3 & $3.0-4.0$ & 3.46 & 1.73 & 2.616 & 38.2 & 0.72 \\
B.H. 4 & $3.0-4.0$ & 6.09 & 4.36 & 5.232 & 48.72 & 0.8 \\
\hline
\end{tabular}

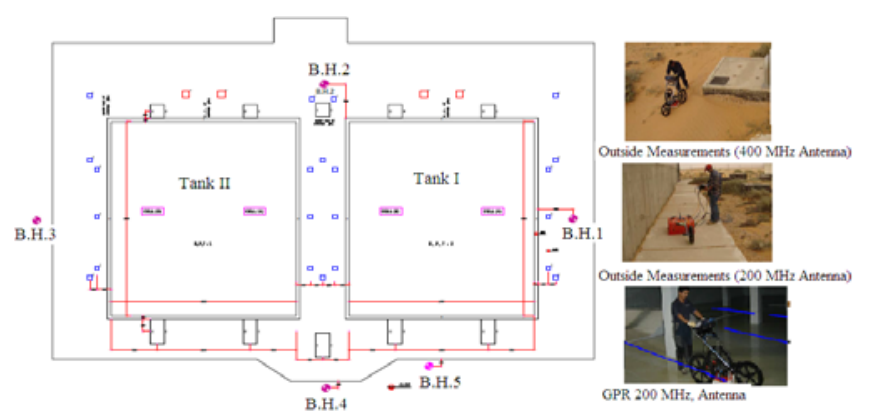

Fig. 2. Tanks layout, borehole position and GPR surveying, outside and inside both tanks.

\section{RESUltS AND DisCUSSIONS}

GPR measurement details were summarized in Fig. 3. It shows approximate location of various types of anomalies detected in both tanks, Tank (I) presents more anomalies than those of tank (П). As the GPR measurement which has taken outside the tanks shows dispersed anomalies. Nevertheless this point should be moderated by the fact that measurements were not taken everywhere and in a continuous way, as shown in Fig. 4 and Fig. 5. Fig. 6 shows the data set as iso-amplitude surfaces, it shows the high reflectivity anomalies position which could be related to the presence cavities of various size and depth.

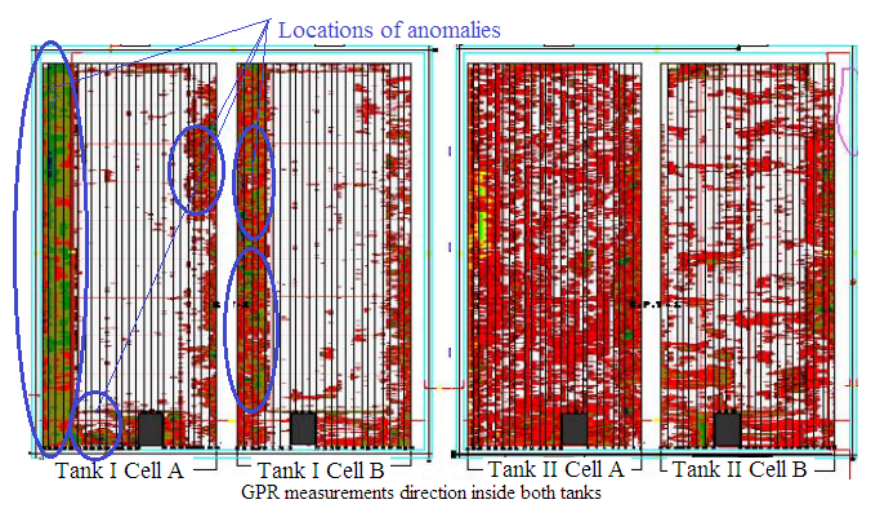

Fig. 3. Locations of anomalies and their antiquaries.

The results of visual inspection and geotechnical and 
geophysical investigations, provided some guidance towards understanding the cause and extent of the problem. The problem we meant here is not limited to the cavity observed at cell (A) of tank (I). There are possible places where unseen small-sized cavities are scattered not only under cell (A) but under other cells as well. The geophysical survey located the positions of many anomalies which exist underneath both tanks, Fig. 3. The anomaly may be a cavity or a type of formation of high reflection of signal indicating loose type of formation which may at any time turn to a cavity. Profiles obtained during the geotechnical investigation indicate the existence of gypsofierous soil at close levels to tank bottom Table I. Whatever the type of formation is (sand, silt or clay), there is evidence of considerable amount of gypsum within the soil mass (expressed as $\left(\mathrm{SO}_{4}\right)$ in Table II. Even though the exploration points were not so close to tanks, they indicate the existence of this type of formation in all positions. Moreover, rock formed crystallized gypsum was also found at variable depths and with variable thicknesses.

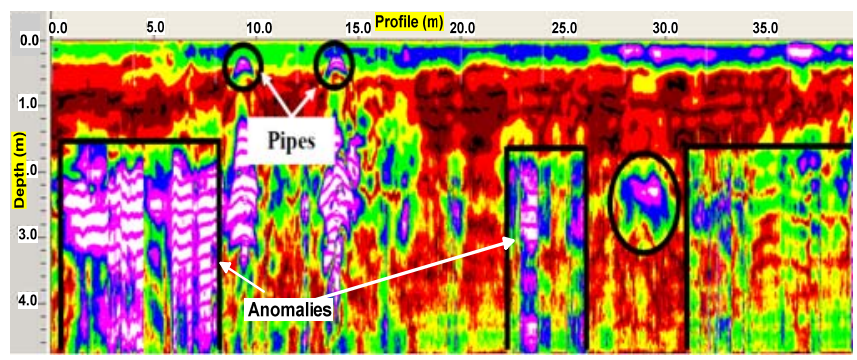

Fig. 4(a). Outside measurements, tank I, cell A, 200MHz.

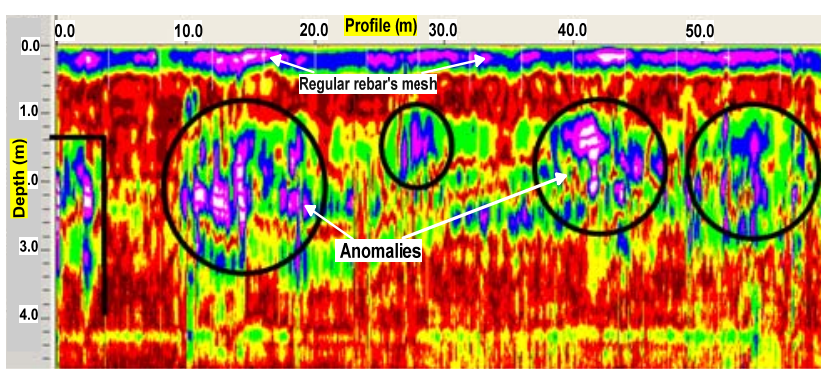

Fig. 4(b). outside measurements, tank I, cell B, $200 \mathrm{MHz}$.

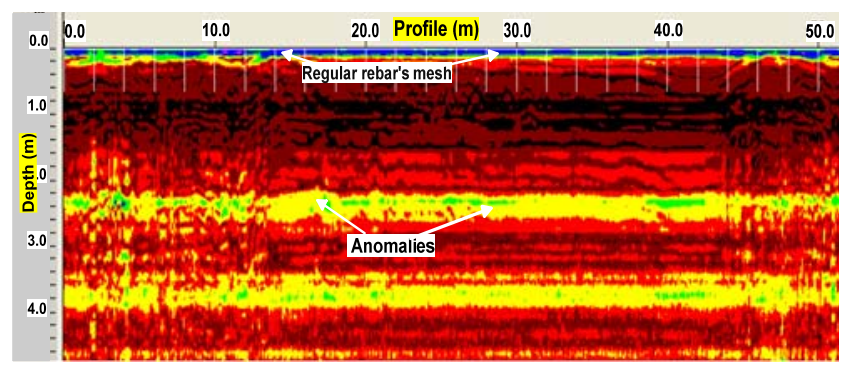

Fig. 5(a). GPR profile close to the damaged cell, tank I, cell A, $400 \mathrm{MHz}$, antenna.

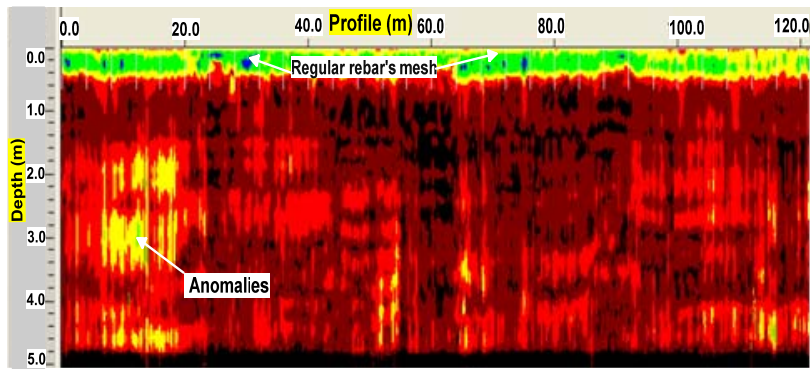

Fig. 5(b). Parallel to tank II, east side $200 \mathrm{MHz}$ antenna.

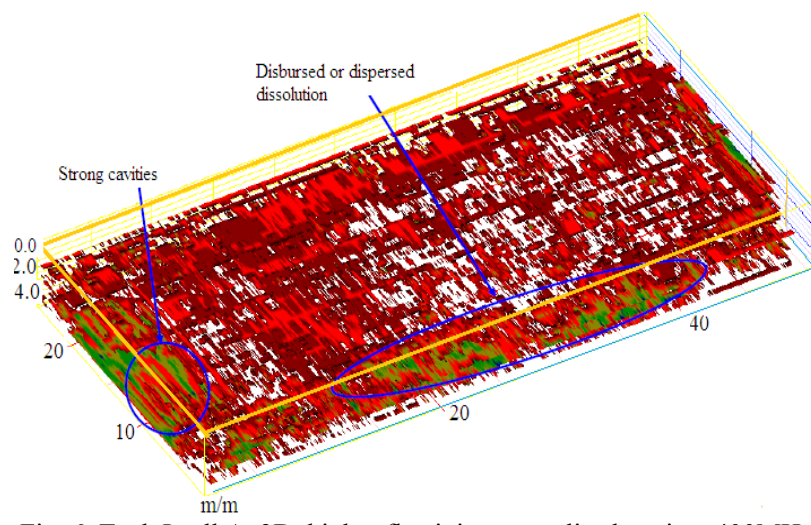

Fig. 6. Tank I cell A, 3D, high reflectivity anomalies location, $400 \mathrm{MHz}$ Antenna.

\section{CONCLUSION}

In this work we demonstrated efficiency of the GPR application in gypsum caves formed underneath the foundations of the break pressure tanks, which are considered invisible. It is shown that the GPR is very attractive equipment not only for detecting caves exploration but to clarify the following points:

1) GPR measurements show clearly the mapping distribution of different anomalies corresponding

2) GPR measurements didn't show significant anomalies in the concrete slab of the both tanks (regular rebar's mesh / homogeneous concrete signal).

3) Tank I presents more important cavities than those of tank II.

4) Tank II seems to be in a better state this is probably significant of a less advanced deterioration stage.

5) Radar measurements taken outside show dispersed anomalies, nevertheless this point should be moderated by the fact that measurements were not taken everywhere and in a continuous way.

6) The geotechnical boreholes done outside of the both water tanks confirm this heterogeneous behavior.

7) This geophysical campaign showed in some locations vertical anomalies close to 5 meter depth. Taking into account the gypseous nature of the basement and these vertical anomalies it is probable that cavities exist more in-depth.

\section{ACKNOWLEDGMENT}

The author would like to thank The Man-made River Water Utilization Authority, Middle Region for the opportunity that gave him to do this research.

\section{REFERENCES}

[1] P. Ulriksen, "Application of impulse radar to civil engineering," Ph.D. Dept. of Eng. Geol. Lund University of Technology, Sweden, 1982.

[2] J. A. Pilon, "Ground penetrating radar," Geological Survey of Canada, pp. 90-94, Ottawa, Canda, 1992.

[3] L. B. Conyers and D. Goodman, "Ground-penetrating radar," $A n$ Introduction for Archaeologists, AltaMira Press, Walnut Creek, California, p. 232, 1997.

[4] S. A. Arcone, D. E. Lawson, A. J. Delaney, J. C. Strasser, and J. D. Strasser, "Ground-penetrating radar reflection profiling of groundwater and bedrock in an area of discontinuous permafrost," Geophysics, vol. 63, pp. 1573-1584, 1998. 
[5] D. A. Noon, G. F. Stickley, and D. Longstaff, "GPR proceedings of the Eighth international conference on ground penetrating radar," SPIE, $\mathrm{p}$. 908, 2000

[6] J. L. Davis and A. P. Annan, "Ground Penetrating Radar for high resolution mapping of soil and rock stratigraphy," Geophysical Prospecting, vol. 37, pp. 531-551, 1989

[7] M. Knez and T. T. Slabe, "Caves and sinkholes in motorway construction," Karst and Cavernous Rocks in Engineering and Construction, pp. $283-288,2005$.

[8] M. U. Pavlič and B. Praznik "Detecting karstic zones in highway construction using ground penetrating radar," Acta Geotechnica Slovenica, no. 1, 2011.

[9] Industrial Research Centre, "Libyan geological map," Esselte Maps, Stockholm, vol. 1, 1985

[10] Libyan Technical Consultancy Co, Design details for An Nowflyia Break, Gmruwa, 1996.

[11] British Standard Institution, Code of Practice for Site Investigations, BS5930, 1999.

[12] R. M. Morey, "Continuous subsurface profiling by impulse radar," in Proc. Engr. Foundation Conference Subsurface Exploration Underground Excavation and Heavy construction, Am. Society Civil Engineers, pp. 213- 232, 1974

[13] C. P. Ulriksen, "Application of impulse radar to civil engineering" Ph. D dissertation, Dept of Engineering Geology, Lund University of Tech, Sweden, 1982.

[14] R. F. Ballard, "Cavity detection and delineation research," Rep.5, Electromagnetic (radar) techniques applied to cavity detection, Tech. Rep. GL-83-1 U. S. A rmy Engr. Waterways Expr Station, Viksburg, MS. 1983.
[15] G. R. Olhoeft, "Application and limitations of ground penetrating radar," in Proc. 54th Annual Intrnational Meeting, Society Exploration Geophysics, Expanded Abstracts, pp. 147-148, 1984

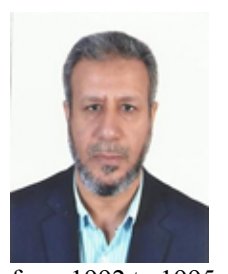

Fathi A. Swaid was born in Misurata, Libya in 1964 He has obtained M.Sc. (1998) in hydrogeology and groundwater management from University of Technology, Sydney, Australia and He has obtained $\mathrm{PhD}$ (2008) in geophysics from University of Technology, Sydney, Australia. He was the head of the first water project aquaculture of the Great Manmade River Water Utilization Authority (GMRUWA), Libya, from 1992 to 1995. (MSc. Student, 1995 - 1998) After his study, he joined as the director of operating and aquaculture of the GMRUW from 1998 to 2003, (PhD Student, 2003- 2008).

Now he is working in the area of soil salinity, irrigation system, cultivation and groundwater salinity and derange with Great Man-made River Water Utilization, Libya. And collaborate in teaching some of materials in Misurata University, faculty of Engineering.

He was assigned numbers of consulting assignments and preparation of technical reports regarding to the water situation in Libya, the study of some soils and suitability for agriculture under permanent irrigation system in the Central Region, the study of infrastructure of the water tanks and detect and identify paths of the drainage channels within the archaeological areas using geophysical methods.

He has published many of research papers in different areas. 